\title{
Intravenous Pyelogram
}

National Cancer Institute

\section{Source}

National Cancer Institute. Intravenous Pyelogram. NCI Thesaurus. Code C17643.

X-ray study of the kidneys, uterus, and urinary tract. Structures are made visible by the IV injection of a substance that blocks $\mathrm{x}$-rays. 